\title{
The effects of temperature change on the infection rate of Biomphalaria glabrata with Schistosoma mansoni
}

\author{
João R Coelho, Fernando SM Bezerra/ ${ }^{+}$
}

Departamento de Análises Clínicas e Toxicológicas, Faculdade de Farmácia, Odontologia e Enfermagem, Universidade Federal do Ceará, Rua Cap. Francisco Pedro 1210, 60430-370 Fortaleza, CE, Brasil

The aim of this study was to investigate the influence of temperature on the development of Schistosoma mansoni infections in Biomphalaria glabrata. The snails were infected at 15,20 , and $30^{\circ} \mathrm{C}$, and the cercarial release was analyzed after 30 and 60 days post-infection. Our results showed that a decrease in the temperature has a substantial influence on the development of $\mathrm{S}$. mansoni infection in $\mathrm{B}$. glabrata, with significant differences $(p<0.05)$ between 15 and $30^{\circ} \mathrm{C}$. These data could provide a better understanding of the epidemiological aspects of schistosomiasis.

Key words: Biomphalaria glabrata - Schistosoma mansoni - temperature

The development of the life cycle of Schistosoma mansoni in its intermediate host is influenced by environmental and endogenous factors. Temperature (Maldonado \& Acosta-Matienzo 1947, Stirewalt 1954) and luminosity (Standen 1951, Valle et al. 1971) are among the most important environmental factors. Typically, miracidium-cercaria transformation takes about 30 days (Pan 1965). The aim of this study is to evaluate the influence of the temperature on S. mansoni infection in Biomphalaria glabrata. Snails in the same age and kept the feeding conditions were incubated at temperatures of 15,20 , and $30^{\circ} \mathrm{C}$ for $12 \mathrm{~h}$ in $\mathrm{BOD}^{\circledR}$ stove; after that they were individually infected with $10 \mathrm{~S}$. mansoni miracidia according to Barbosa and Barreto (1960) technique, and kept at the same temperature for the same period of time. The group comprised 30 snails each and the proceeding was made in triplicate.

Afterwards, the groups were individually replaced in aquariums at room temperature, and weekly analyzed until the 60th day after infection concerning the cercarial release. The results were analyzed by the ANOVA test (Zar 1996).

Our results show a direct relationship between temperature and infection rate, i.e. the lower temperature is the lowest is the infection level of $B$. glabrata with $S$. mansoni. The differences among the temperatures of 15 and $20^{\circ} \mathrm{C}(\mathrm{P}<0.01), 20$ and $30^{\circ} \mathrm{C}(\mathrm{P}<0.01)$, and 15 and $30^{\circ} \mathrm{C}$ $(\mathrm{P}<0.0001)$ were statistically significant. When the temperature was $15^{\circ} \mathrm{C}$ only $1.3 \%$ of the B. glabrata exposed to $S$. mansoni became infected, whereas when the temperature were 20 and $30^{\circ} \mathrm{C}$ the rates were 46 and $89 \%$, respectively (Figure).

\footnotetext{
Financial support: Funcap

+Corresponding autor: bezerra@ufc.br

Received 8 December 2005

Accepted 31 January 2006
}

The success of the snail infection by a trematode depends at least on three main factors: the age of the snail at exposure, the temperature of the water in which the snail and the parasite are located, and the mollusc nutritional status, which determines a more or less fast growth of the snail throughout infection (Smyth \& Hailton 1983). An important factor of success of $B$. glabrata infection with $S$. mansoni is the temperature at the moment of contact between the host and the parasite. Maldonado and Acosta-Matienzo (1947) demonstrated that the decrease of $1^{\circ} \mathrm{C}$ in the water temperature (from 26 to $25^{\circ} \mathrm{C}$ ) caused a decrease of $50 \%$ in the infection level, which used to be $80 \%$ at $26^{\circ} \mathrm{C}$. Similar results were found by Standen (1951). Stirewalt (1954) studied the effect of temperature maintenance on development of S. mansoni intramollusc. The obtained results demonstrated that in determined stages, the relationship between trematoda and mollusc was strongly influenced by the temperature reduction, occurring a delay in the release and a strong reduction in the number of eliminated cercariae by each snail individually. In some cases, a total stoppage occurred in the sporocyst development in snails kept at temperatures from 23 to $25^{\circ} \mathrm{C}$ after miracidia exposition. Under the epidemiological point of view, the temperature is of great importance. Climatic changes occurred in some Brazilian regions could cause

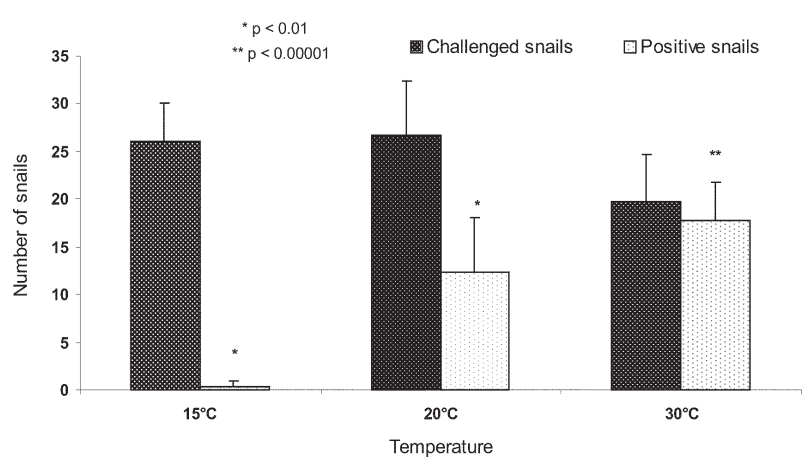

Variation of the infection rate in Biomphalaria glabrata snails infected with Schistosoma mansoni in three different temperatures. 
changes in the schistosomiasis index prevalence, especially in endemic areas where a persistent cold wind occurs.

\section{ACKNOWLEDGEMENTS}

To Dr J Russell Stothard and Dr Fiona Allan from the Natural History Museum, London, for their improvement of the English version of the manuscript and also to Dr Rene D Martins for the statistical analysis support.

\section{REFERENCES}

Barbosa FS, Barreto AC 1960. Differences in susceptibility of Brazilians strains of Australorbis glabratus to Schistosoma mansoni. Exp Parasitol 9: 137-140.

Maldonado JF, Acosta-Matienzo J 1947. The development of Schistosoma mansoni in the snail intermediate host, Australorbis glabratus. Puerto Rican J Pub Health and Trop Med 22: 374-404.
Pan C 1965. Studies on the host-parasite relationship between Schistosoma mansoni and the snail Australorbis glabratus. Am J Trop Med Hyg 14: 931-976.

Smith JD, Hailton DW 1983. The Physiology of Trematodes, Cambridge Univ Press, Cambridge, 446 pp.

Stirewalt MA 1954. Effect of snail maintenance temperatures on development of Schistosoma mansoni. Exp Parasitol 33: 504-516.

Standen OD 1951. The effect of temperature, light and salinity upon the hatching of the ova of Schistosoma mansoni. Trans $R$ Soc Trop Med Hyg 45: 225-241.

Valle CM, Pellegrino J, Alvarenga N 1971. Ritmo circadiano de emergência de cercárias (Schistosoma mansoni-Biomphalaria glabrata). Rev Bras Biol 31: 53-63.

Zar JH 1996. Biostatistical Analysis, 3rd ed., Prentice-Hall, New Jersey, $662 \mathrm{pp}$. 